\author{
Esen Arkis, Hayrullah Cetinkaya, Isil Kurtulus, Utku Ulucan, Arda Aytac, \\ Beste Balci, Funda Colak, Ece Germen, Gulistan Kutluay, Begum Dilhan \\ and Devrim Balkose
}

\title{
CHARACTERIZATION OF A PEARLESCENT BIAXIALLY ORIENTED MULTILAYER POLYPROPYLENE FILM
}

\author{
Izmir Institute of Technology, \\ Gulbahce Urla 35430, Urla Izmir, Turkey; devrimbalkose@gmail.com
}

Received: September 09, 2014 / Revised: September 23, 2014 / Accepted: November 03, 2014

(C) Arkis E., Cetinkaya H., Kurtulus I., Ulucan U., Aytac A., Balci B., Colak F., Germen E., Kutluay G., Dilhan B., Balkose D., 2015

\begin{abstract}
The morphology, composition, optical, thermal and mechanical properties of a commercial pearlescent and multilayer biaxially oriented polypropylene (BOPP) films were determined. The structure and orientation of BOPP films were confirmed by FTIR spectroscopy, X-ray diffraction and EDX analysis. The films surface roughness was determined by AFM method. The tensile strength of the films was determined in machine and transverse directions.
\end{abstract}

Keywords: pearlescent film, biaxially oriented polypropylene, X-ray diffraction, AFM, tensile strength.

\section{Introduction}

Polypropylene (PP) is one of the most preferred polymer in food packing, protective coating and printing applications with its high stiffness, high temperature resistance, good chemical resistance, lower moisture transmission rate and high mechanical stress properties [1-4]. The polypropylene film that is stretched in both machine direction (MD) and across machine (transverse) direction to improve mechanical properties is called biaxially oriented polypropylene (BOPP). BOPP is widely used in packaging and in a variety of other applications due to their great potential in terms of barrier properties, brilliance, dimensional stability and processability [2]. Different fillers such as talc and calcium carbonate and pigments may be added to BOPP films in order to improve its optical properties and provide a pearly aesthetic look [5, 6]. Thus flexible packaging companies are willing to use pearl films for their inexpensive prices, good decoration, and excellent performance. Generally, because they have a certain pearl effect, they are often used in cold drink packaging such as: ice cream, heat seal label, sweet food, biscuits, and local flavor snack packaging [1].

Mineral particles, such as calcium carbonate and talc powders, are widely used in biaxially oriented films, which are also called cavitated and pearlized structures. Pearled film is based on the orientation process, where the interface around the particles is stretched forming small cavities in the polymer structure. The foam extent of the film is low but the film becomes highly opaque because of inter scratches $[4,7,8]$. Pearl film is a kind of BOPP film by adding pearl pigments into plastic particles and through biaxial stretch heat setting. A typical pearl film is BOPP pearl film produced by A/B/A layer co-extruded biaxial stretch [9]. Three layer films are coextruded, where the surface is optimized in order to attain good printability. In fact, the more pigment is in the system, the more light is scattered outward, making the system appear opaque and white [10]. Calcium carbonate particles having 0.7-3 $\mu \mathrm{m}$ size are often used in producing microporous films [11].

The surface morphology of BOPP film could be investigated by an atomic force microscopy. The polymer film is characterized by a nanometer-scale, fiber-like network structure, which reflects the drawing process used during the fabrication of the film. The residual effects of the first stretching of the film surface can provide information on the way in which morphological development of BOPP occurs [12, 13].

The aim of the present study is characterization of a commercial pearlescent BOPP film by advanced analytical techniques. The functional groups, crystal structure, morphology, surface roughness, light transmission 
and reflection, melting and thermal degradation of the film and mechanical properties were investigated.

\section{Experimental}

\subsection{M aterials}

The pearlescent films that were kindly supplied by BAK Ambalaj Turkey were produced at their plant in Izmir. They were kindly supplied in form of A4 sized sheets with $30 \mu \mathrm{m}$ thickness.

\subsection{M ethods}

The functional groups in the pearlescent film were determined by the infrared spectroscopy. IRPrestige-21 FT-IR 8400 S by Shimadzu was used to obtain FTIR spectrum of the film by transmission technique. DRIFT FTIR spectra of both surfaces of the film were obtained in Digilab Excalibur FTIR spectrophotometer using Harricks Praying Mantis attachment.

Crystal structre of the films were determined by Xray diffraction using Phillips X'Pert Pro diffractometer system . $\mathrm{Cu} \mathrm{K \alpha}$ radiation was used and a scan rate of $2^{\circ} \theta /$ min was applied.

SEM micrographs of upper and lower surfaces and cross section of gold coated Pearlescent BOPP films taken by FEI Quanta 250 FEG type scanning electron microscope. Chemical composition of the film surface was determined by EDX analysis using the same instrument.

AFM (Nanoscope IV) and silicon tip were used to obtain surface morphology and roughness of the film. $1 \mathrm{Ohm}$ Silicon tip has a coating: front side - none; back side $-50 \pm 10 \mathrm{~nm}$ Al. Cantilever properties are: $\mathrm{T} 3.6-5.6 \mu \mathrm{m}$, L $140-180 \mu \mathrm{m}, \mathrm{k} 12-103 \mathrm{~N} / \mathrm{m}$, fo $330-359 \mathrm{kHz}$, $\mathrm{W} 48-52 \mu \mathrm{m}$. To achieve surface properties of the pearlescent BOPP film, it was cut in 1x1 cm size, then it was put in the sample holder in AFM. USRS 99-010, AS 01158-060 serial no OD57C-3930 standard was used in a reflection mode. For the reflection spectrum, a black CD was placed at the back of the film.

The film was thermally treated under pressure to eliminate its pores. Thus the transparency of the perlescent film and heat treated film were tested. The pearlescent film thickness was reduced from 30 to nearly $23 \mu \mathrm{m}$ by a compression molding machine (Shinto) in two stages. Film is was preheated in the hot press for 3 min without pressure, then heated for $3 \mathrm{~min}$ at $5.88 \mathrm{MPa}$. After this stage, the film was placed in a cold press for $3 \mathrm{~min}$ at 14.7 $\mathrm{MPa}$. The light transmission from the films was tested by covering the surface of a paper with our Institute's logo.

The stress strain diagrams of the film in machine direction and transverse direction were obtained with Texture Analyser TA-XT2 (Stable microsystem, Godalming, UK) having Exponent stable Micro Sytem software. The test is done in ASTM D882. The strips with $5 \mathrm{~mm}$ width and $10 \mathrm{~mm}$ length were strained with $5 \mathrm{~mm} / \mathrm{min}$ rate.

\section{Results and Discussion}

\subsection{FTIR Spectroscopy}

Fig. 1a shows the pearlescent BOPP film FTIR spectrum taken by the transmission method. The peaks between 2950 and $2800 \mathrm{~cm}^{-1}$ correspond to various aliphatic $\mathrm{CH}$ stretching modes. The peaks near $1450 \mathrm{~cm}^{-1}$ and $1380 \mathrm{~cm}^{-1}$ are $\mathrm{CH}_{2}$ and $\mathrm{CH}_{3}$ deformation bands, respectively [14]. The other peaks below $1400 \mathrm{~cm}^{-1}$ are the well-known "fingerprint" of isotactic PP. The peak at around $1500 \mathrm{~cm}^{-1}$ of the pearlescent BOPP film is wide which is caused by the existence of calcite. The reason of the increase of the peaks around this region is calcite. The bands at $\sim 1420, \sim 874$ and $\sim 712 \mathrm{~cm}^{-1}$ could be attributed to vibrations of $\mathrm{CO}_{3}$ group of calcite [15].

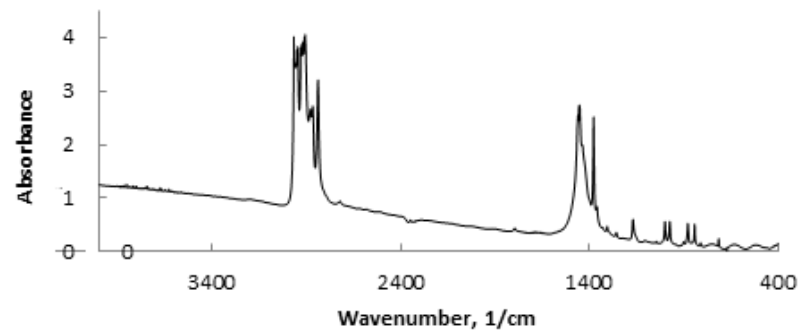

(a)

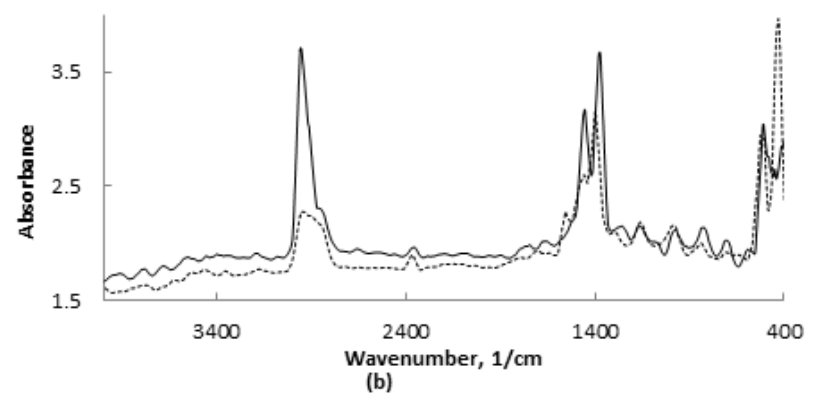

Fig. 1. Transmission FTIR spectrum (a) and DRIFT FTIR spectra (b) of front (dotted line) and back (continuous line) surfaces of the pearlescent BOPP film 


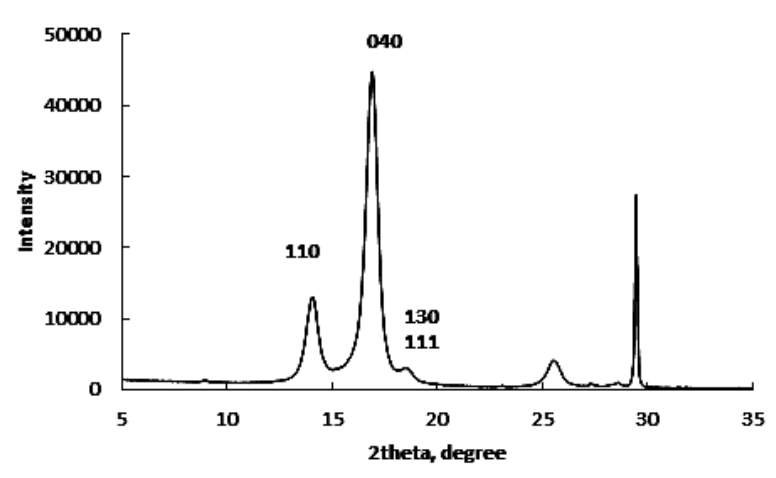

Fig. 2. X-ray diffraction diagram of the film in $5-35^{\circ}$ 2 theta range

DRIFT FTIR spectra of both surfaces of the film are seen in Fig. 1b. The peak around $3000 \mathrm{~cm}^{-1}$ for back surface is similar to the previous result but for the front surface, the peak is very small. The spectra of the surfaces of the pearlescent film were very different from the transmission spectrum, indicating they were made out of different polymers. PVdC and acrylic coatings were used for making the pearlescent film heat sealable and printable. However without further characterizations it was not possible to identify the polymer surfaces of the film.

\subsection{X-ray Diffraction}

In Fig. 2 X-ray diffraction diagram of the film in 5$35^{\circ} 2$ theta range is seen. The maximum reflection points of biaxially oriented isotactic polypropylene were observed at $14.2^{\circ}(110) ; 17^{\circ}(040) ; 18.85^{\circ}$ (130); (111) $21.4^{\circ}$; (-131) $21.8^{\circ} 2$ theta values (Fig. 2) [16].

The sharp peak at $29.4^{\circ} 2$ theta value can be attributed to 104 planes of calcite. X-ray diffraction diagram of the film in $35-65^{\circ} 2$ theta values is seen in Fig. 3. Observed peaks at $36.03,39.4,43.2,47.2,47.4,47.6$ and $48.5^{\circ} 2$ theta values are very close to peaks of calcite reported in JCPDS Card Index File, Card 5-5868 [17], which two theta values are of 36.03, 39.4, 43.2, 47.2, 47.5 and 48.6. Thus the presence of calcite was also confirmed by X-ray diffraction.

\subsection{SEM and EDX}

The SEM micrographs of the cross sections of the film in machine and transverse direction are seen in Fig. 4. The film has three-layered structure. The top and bottom surface layers which had thickness of $4 \mu \mathrm{m}$ do not have any solid particles. FTIR analysis had indicated that the two surfaces were made out of two different polymers other than the core layer. SEM micrographs of the surfaces indicated that they were very smooth. The core layer with $22 \mu \mathrm{m}$ thickness had a stratified structure.

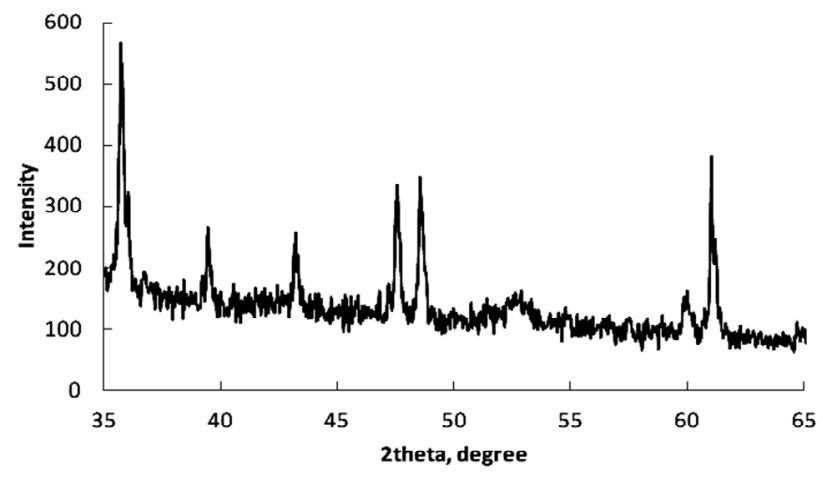

Fig. 3. X-ray diffraction diagram of the film in $35-65^{\circ} 2$ theta range

There were holes having very high aspect ratio created by $0.8-3 \mu \mathrm{m}$ sized particles and the orientation process. The dimensions of the pores in machine direction are of $16.4 \pm 6.2 \mu \mathrm{m}$ length and of $0.7 \pm 0.3 \mu \mathrm{m}$ width, in transverse direction they are of $9.14 \pm 3.99 \mu \mathrm{m}$ length and of $0.47 \pm 0.5 \mu \mathrm{m}$ width. Mean aspect ratios (length/width) of pores observed in Figs. $4 \mathrm{a}$ and $4 \mathrm{~b}$ are 23 and 19, respectively.

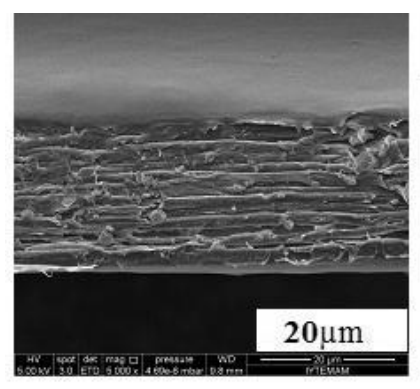

a)

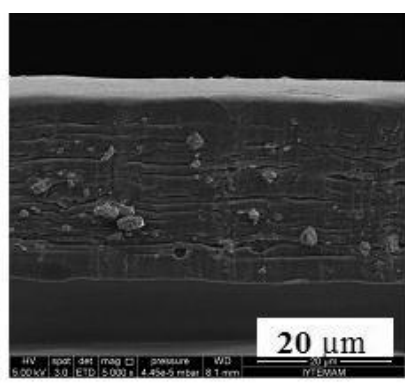

b)
Fig. 4. SEM micrographs of the cross-sections of the film in machine (a) and transverse direction (b)

The EDX analysis of the surface of the filler particles indicated that they consisted of $\mathrm{Ca}, \mathrm{C}$ and $\mathrm{O}$ elements. They had a composition similar to $\mathrm{CaCO}_{3}$ which had $40 \% \mathrm{Ca}, 12 \% \mathrm{C}$ and $48 \% \mathrm{O}$. EDX analysis of the particles showed that the particles had $42.8 \pm 1.6 \% \mathrm{Ca}, 22.3 \pm 3.73 \% \mathrm{C}$ and $34.9 \pm 5.2 \% \mathrm{O}$. The particles were calcite and they were coated by a compound which was rich in $\mathrm{C}$.

\subsection{AFM study}

Typical images of the surface of the pearlescent film in two and three dimensions are seen in Fig. 5. The surface consists of spherical particles. No network structure was observed as indicated by previous studies for 8:1 draw ratio, indicating the draw ratio of the 
pearlescent film in machine and transverse direction were close to each other. The surface roughness of the films were determined in three different regions and reported in Table 1 . The rootmean square roughness (Rms) was between 3.052 and $11.261 \mathrm{~nm}$ and the average roughness (Ra) was in the range of $2.330-7.326 \mathrm{~nm}$. This low roughness values indicated that the surface of the pearlescent films was very smooth.

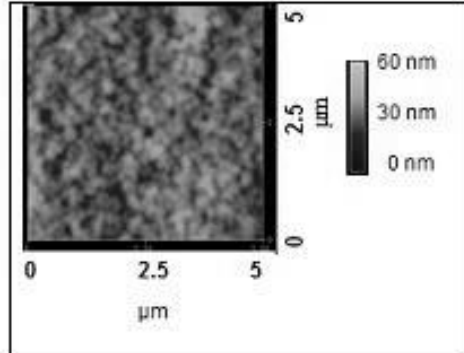

a)

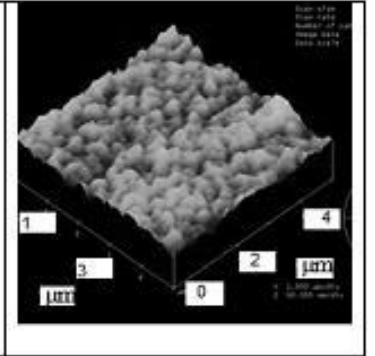

b)
Fig. 5. AFM micrographs of the surface of the pearlescent films: two dimensional image (a) and three-dimensional image (b). Vertical scale $60 \mathrm{~nm} / \mathrm{div}$, horizontal scale $1 \mu \mathrm{m} / \mathrm{div}$

\subsection{DSC Analysis}

DSC analysis was used to determine the melting point, melting heat and crystallinity, the crystallite size and activation energy of the melting process. The DSC curves of the sample heated at different rates are seen in Fig. 6. A shoulder corresponding to the melting of small crystallites was observed at all heating rates. This shoulder was also observed for biaxial oriented polypropylene by previous investigators [18]. The melting temperature shifts to higher temperatures as the rate of heating was increased. Table 2 shows enthalpy of melting, melting temperature and crystallinity determined at different rates of heating of the film.

The degree of crystallinity $\left(X_{c}\right)$ of the samples from DSC melting peaks were determined using Eq. (1).

$$
X_{c}(\%)=\frac{\Delta H_{m}}{w \Delta H_{f}^{0}} \cdot 100
$$

where $\Delta H_{m}$ is the melting enthalpy of the samples, $\mathrm{J} / \mathrm{g}$; $\Delta H_{f}^{0}$ is the heat of PP fusion at $100 \%$ crystallinity, corresponding to $207 \mathrm{~J} / \mathrm{g}$ [18].

The crystallinity of the film also increases with the rate of heating. $\Delta H_{m}$ was calculated from the areas of the melting peaks for different heating rates in Fig. 6. The Thompson-Gibbs equation predicts a linear relationship between $T_{m}$ and the reciprocal of crystal thickness.

$$
T_{m}=T_{m}^{0}\left(1-\frac{2 \sigma}{L_{c} \rho_{c} \Delta H_{f}^{0}}\right)
$$

where $\sigma$ is the fold surface free energy, $T_{m}^{0}$ is the equilibrium melting temperature, $\rho_{c}$ is the crystal phase density of PP, $\Delta H_{f}^{0}$ is the heat of the fusion of PP at $100 \%$ crystallinity, corresponding to $207 \mathrm{~J} / \mathrm{g}$ [19], and $L_{c}$ is the thickness of the lamellar crystals.

$$
T_{m}^{0} \text { is } 459.1 \mathrm{~K} \text { [20], } \rho_{c} \text { is } 946 \mathrm{~kg} / \mathrm{m}^{3} \text { [21] and } \sigma \text { is }
$$

$30.1 \mathrm{mN} / \mathrm{m}$ [22]. The crystal thickness values determined by using the melting temperature for different heating rates are reported in Table 2 . They were within the range of $6.1-6.5 \mathrm{~nm}$.

Table 1

Image statistics of pearlescent BOPP films at three different regions

\begin{tabular}{|l|c|c|c|}
\hline \multicolumn{1}{|c|}{ Scan size, $\mu \mathrm{m} \times \mu \mathrm{m}$} & $5 \times 5$ & $5 \times 5$ & $1 \times 1$ \\
\hline$Z$ range, $\mathrm{nm}$ & 38.155 & 113.93 & 21.031 \\
\hline Raw mean, $\mathrm{nm}$ & 25.591 & 53.191 & -37.563 \\
\hline Rms $(\mathrm{Rq}), \mathrm{nm}$ & 4.861 & 11.261 & 3.052 \\
\hline Ra, $\mathrm{nm}$ & 3.821 & 7.326 & 2.330 \\
\hline Srf. area, $\mu \mathrm{m}^{2}$ & 25.057 & 25.121 & 1.003 \\
\hline
\end{tabular}

Table 2

Enthalpy of melting, melting temperature and crystallinity determined by DSC

\begin{tabular}{|c|c|c|c|c|}
\hline Heating rate, $\mathrm{K} / \mathrm{min}$ & $\Delta H_{m}, \mathrm{~J} / \mathrm{g}$ & $T_{m}, \mathrm{~K}$ & Crystallinity, \% & Lc, $\mathrm{nm}$ \\
\hline 5 & 87.63 & 435.9 & 48 & 6.1 \\
\hline 10 & 93.75 & 436.6 & 51 & 6.3 \\
\hline 15 & 129.07 & 437.2 & 60 & 6.5 \\
\hline
\end{tabular}




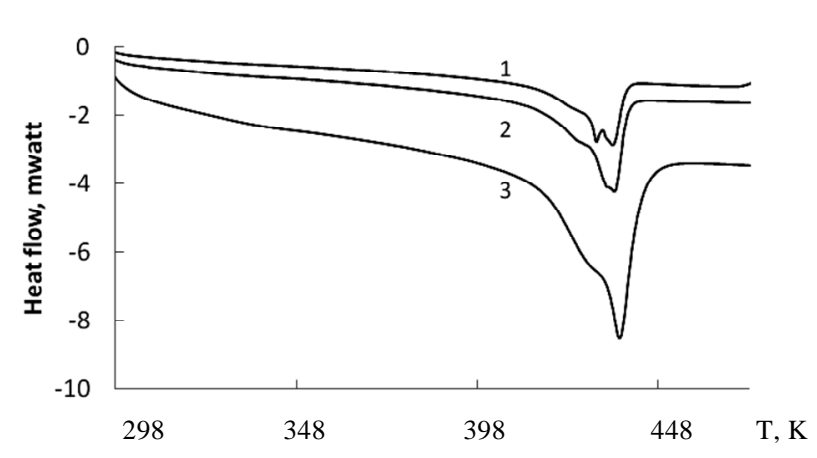

Fig. 6. DSC curves of the film at: $5 \mathrm{~K} / \mathrm{min}$ (1); $10 \mathrm{~K} / \mathrm{min}$ (2) and $15 \mathrm{~K} / \mathrm{min}(3)$ heating rates

\subsection{TG Analysis}

Thermogravimetric analysis (TGA) method was also employed to understand a thermal degradation behavior of the BOPP film. Typical weight loss (TGA) curves of BOPP film at heating rate of 5,10 and $15 \mathrm{~K} / \mathrm{min}$ under nitrogen is seen in Fig. 7. It is observed that the thermal degradation process of the BOPP film proceeds in two stages. The first stage corresponds to the degradation of polymer. The second stage is related to the decomposition of calcium carbonate. The degradation of the BOPP film started at 508, 531 and $538 \mathrm{~K}$ at heating rate of 5,10 and $15 \mathrm{~K} / \mathrm{min}$, respectively. The maximum rate of BOPP film degradation was $631,677.6$ and $685 \mathrm{~K}$ at heating rate of 5,10 and $15 \mathrm{~K} / \mathrm{min}$, respectively. The second step of the mass loss observed in Fig. 7 was for the decomposition of calcite. Fig. 7 displays that the degradation of the calcium carbonate started at 921, 943 and $948 \mathrm{~K}$ at heating rate of 5,10 and $15 \mathrm{~K} / \mathrm{min}$ and its rate was maximum at $963,994.5$ and $987.7 \mathrm{~K}$ at heating rate of 5,10 and $15 \mathrm{~K} / \mathrm{min}$, respectively.

The second stage of the mass loss belongs to decomposition of calcium carbonate. The calcium carbonate decomposes to calcium oxide and carbon dioxide:

$$
\mathrm{CaCO}_{3(\mathrm{~s})} \rightarrow \mathrm{CaO}_{(\mathrm{s})}+\mathrm{CO}_{2(\mathrm{~g})}
$$

If one mole of calcium carbonate decomposes, one mole of calcium oxide and one mole of carbon dioxide would form. Thus the second step is for the evolution of

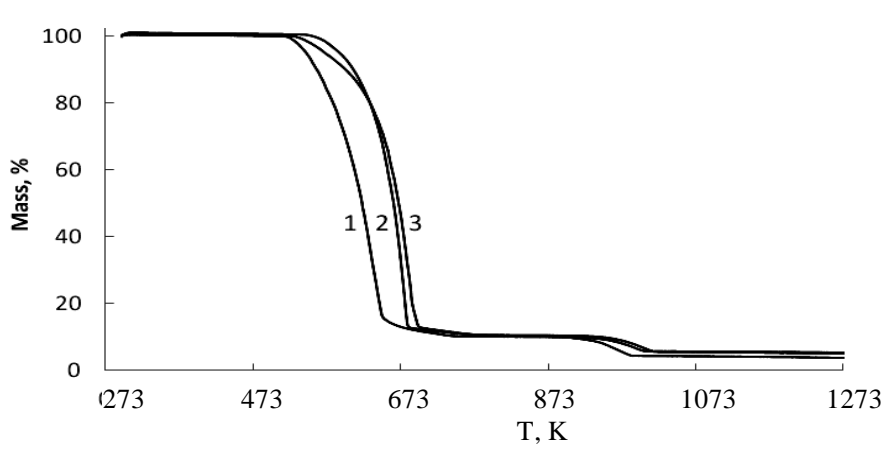

Fig. 7. TG curves of the film at: $5 \mathrm{~K} / \mathrm{min}(1) ; 10 \mathrm{~K} / \mathrm{min}$ (2) and $15 \mathrm{~K} / \mathrm{min}(3)$ heating rates

$\mathrm{CO}_{2}$ from $\mathrm{CaCO}_{3}$. From the mass loss of the second step of the degradation curve it was found that the film contained $11.2 \% \mathrm{CaCO}_{3}$.

In this study decomposition activation energy was determined by using Flynn and Wall equation. Flynn and Wall derived a convenient method to determine the activation energy from weight loss curves measured at several heating rates. The following relationship is used to calculate the activation energy [23].

$$
E=\frac{-R}{b\left[\frac{d \log (\beta)}{d\left(\frac{1}{T}\right)}\right]}
$$

where $E$ - activation energy, $\mathrm{J} / \mathrm{mol} ; R$ - gas constant $(8.314 \mathrm{~J} / \mathrm{mol} \mathrm{K})$ and $b$ - constant equal to 0.457 [23].

The values of 1,2 and $5 \%$ decomposition level were chosen to determine the activation energy for degradation of the polypropylene and temperatures for these conversions were red from Fig. 7. The activation energy was determined directly by plotting the logarithm of the heating rate versus $1000 / T$ at constant conversion. The plotted data produced straight lines with $R^{2}$ values higher than 0.93 . From the slopes the activation energy values were found and they are reported in Table 3. The average activation energy was $64.8 \mathrm{~kJ} / \mathrm{mol}$.

Table 3

Activation energy for degradation of polypropylene and calcite

\begin{tabular}{|c|c|c|c|c|c|}
\hline \multicolumn{3}{|c|}{ Polypropylene } & \multicolumn{3}{c|}{ Calcite } \\
\hline Mass loss, $\%$ & $R^{2}$ value & $E_{a}, \mathrm{~kJ} / \mathrm{mol}$ & Mass loss, $\%$ & $R^{2}$ value & $E_{a}, \mathrm{~kJ} / \mathrm{mol}$ \\
\hline 1 & 0.99 & 64.8 & 91 & 0.98 & -89.5 \\
\hline 2 & 0.96 & 66.4 & 92 & 0.99 & -95.8 \\
\hline 5 & 0.93 & 63.4 & 93 & 0.99 & -95.6 \\
\hline
\end{tabular}


The activation energy for the decomposition of the calcite in the film was determined in the same manner and reported in Table 3 . The average activation energy for the decomposition of calcite was found as $-93.7 \mathrm{~kJ} / \mathrm{mol}$.

\subsection{Optical Properties}

The unique luster of pearls depends upon the reflection, refraction, and diffraction of light from the translucent layers. The thinner and more numerous the layers in the pearl, the finer the luster. The iridescence that pearls display is caused by the overlapping of successive layers, which breaks up light falling on the surface [24]. The film under study had polypropylene layers separated by long and thin air pockets formed by orientation process and calcite particles as seen from the electron micrograph in Fig. 4. Thus it shows pearlescent behavior.

Polypropylene polymer can reflect only a very small percentage of incoming light

$$
R=\frac{\left(n_{1}-n_{2}\right)^{2}}{\left(n_{1}+n_{2}\right)^{2}}
$$

In the above equation, $n_{1}$ and $n_{2}$ indicate the reflection indices of polypropylene and air, respectively. Reflection values were calculated considering Frensel's equation. Reflection index of polypropylene is 1.49 and 1.0 for air [25]. Then, reflection $(R, \%)$ was calculated as $3.87 \%$. However the film under study reflects $85 \%$ of light at $400 \mathrm{~nm}$ and $65 \%$ at $700 \mathrm{~nm}$ as seen in its reflection spectrum in Fig. 8. The thin layers and the air gaps between them is the cause of this pearlescent effect.

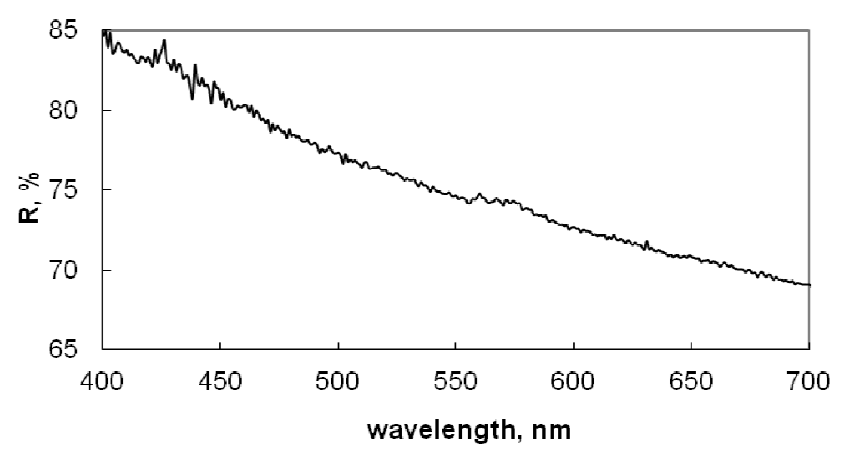

Fig. 8. Reflection spectrum of the studied film

It was reported that the BOPP films were transparent to light and the smoother surface they had, the more transparent they were [26]. It followed that the clearest films were obtained from sheets with the most homogeneous texture, such as obtained by quenching from the melt, and by orienting at the lowest temperature, which minimized the amount of melting [26]. The film in the present study was a sandwich type BOPP film having a core layer with calcite. The film reflects light but it does not transmit it. The transmission spectrum of the film in Fig. 9 indicated that $0.36 \%$ of incident light was transmitted at $400 \mathrm{~nm}$ and $0.5 \%$ was transmitted at $700 \mathrm{~nm}$.

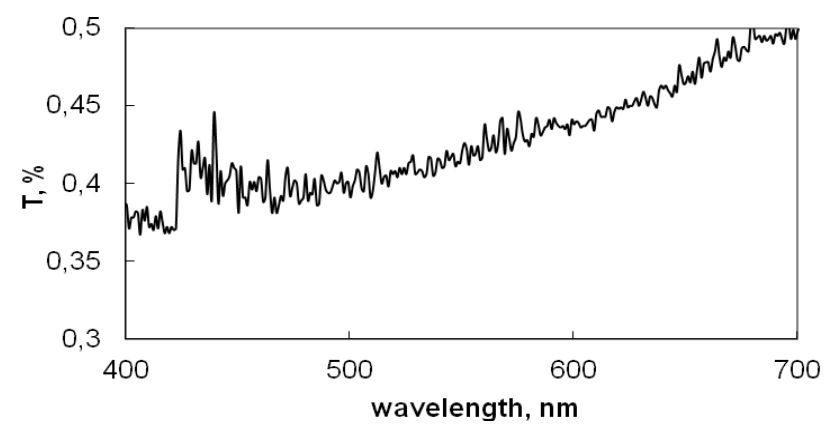

Fig. 9. Transmission spectrum of the film in a visible region

The light was not transmitted from the film because of the air holes in the film. When these holes were removed by hot pressing the film, it became transparent as seen in Fig. 10. The logo of our Institute covered by the pressed film was visible, but when the logo was covered by the pearlescent film it was not visible. The pearlescent film was opaque and when the air holes were removed it was transparent even if it contained $12 \%$ of calcite. It was the air gaps but not the calcite making the film opaque and pearlescent.

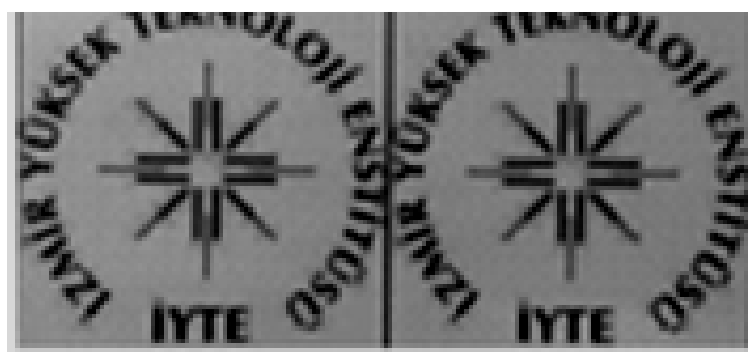

a

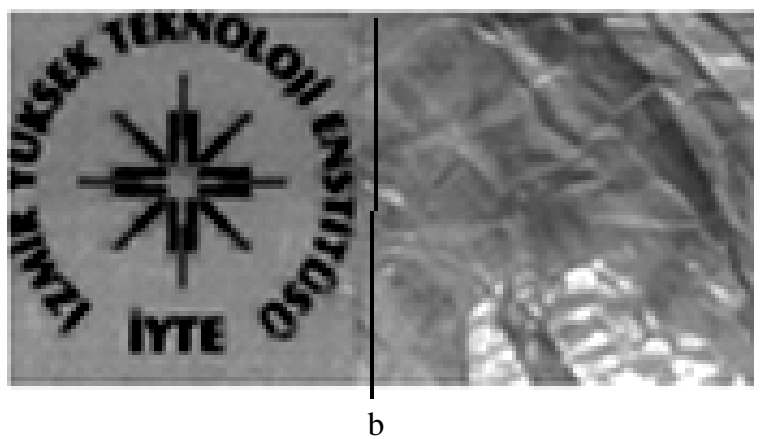

Fig. 10. Paper surface without sample films (a) and covered with sample films (b). Left side was covered with nearly 23 micron pressed film. Right side was covered with 30 micron original white BOPP film 


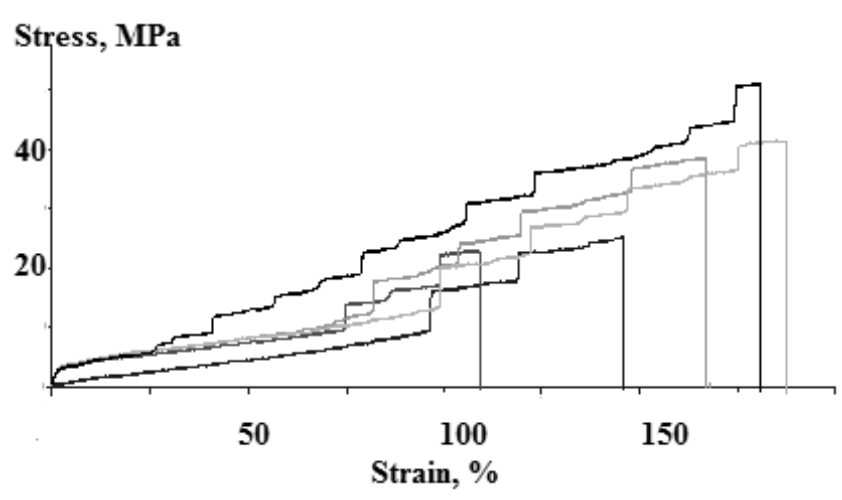

Fig. 11. Stress strain curve of the film in transverse direction

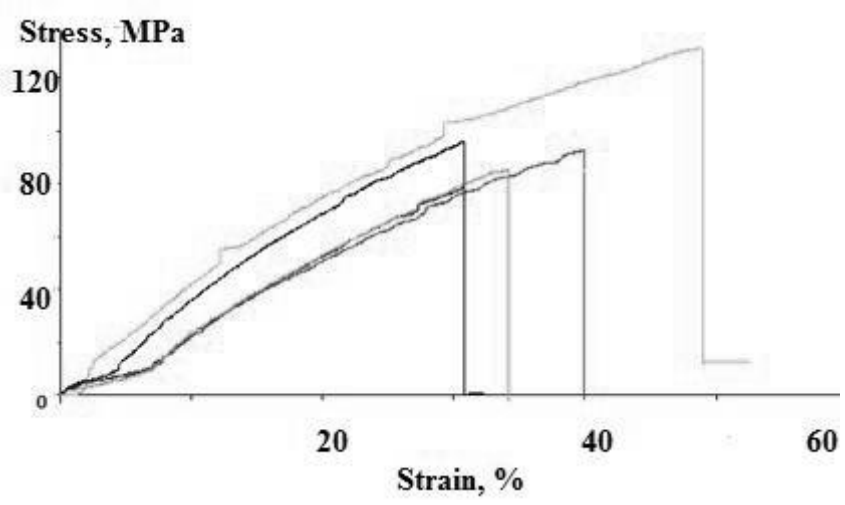

Fig. 12. Strain stress diagram of the film in machine direction

Table 4

Mechanical properties of the film in machine and transverse directions

\begin{tabular}{|l|c|c|c|}
\hline \multicolumn{1}{|c|}{ Direction } & Stress, MPa & Strain, \% & Young modulus, MPa/\% \\
\hline Transverse & $35.9 \pm 11.62$ & $157.7 \pm 31$ & $0.129 \pm 0.065$ \\
\hline Machine & $97.2 \pm 20.6$ & $37 \pm 7.7$ & $2.93 \pm 0.51$ \\
\hline
\end{tabular}

\subsection{M echanical Properties}

The mechanical properties of BOPP in machine and transverse direction are different. In Figs. 11 and 12 stress strain diagrams of the film in transverse and machine directions are seen. The tensile strength in transverse direction is lower and strain at break is higher than those of machine direction as reported in Table 4: tensile stress of 35.9 and $97.7 \mathrm{MPa}$, elongation at break of 157 and $37 \%$ for transverse and machine directions were observed, respectively. No yield point was observed in the BOPP film with calcite. BOPP film without calcite was characterized by Yuksekkalayci et al. [27] and it had the yield point of 34.2 and 42.2 MPa machine and transverse direction, respectively. The film without calcite had higher values of tensile stress (151 and $270 \mathrm{MPa}$ ) [27] in machine and transverse directions than the film with calcite. However the elongation at break values (150 and $32 \%$ ) were closed to the values for the film with calcite. The presence of pores lowers the tensile strength, however the elongation values were closer. The modulus of elasticity of the film under study also changed with direction. It was lower $(0.129 \mathrm{MPa} / \%)$ in transverse direction than in machine direction (2.93 $\mathrm{MPa} / \%)$. However the film without calcite had much higher elastic modulus values 2.8 to $5.9 \mathrm{GPa}$. Thus the calcite filled BOPP film was much more flexible than the film without calcite. This could be due to the porous structure of the pearlescent film.

\section{Conclusions}

A pearlescent packing material supplied by BAK Ambalaj Turkey was characterized for obtaining information about its properties for its application fields and its recycle in industry. The advanced characterization techniques such as FTIR spectroscopy, X-ray diffraction, SEM, EDX, AFM, DSC, TG analysis, visible spectroscopy and tensile testing were used for this purpose. The bulk film was polypropylene and it was biaxially oriented as shown by FTIR spectroscopy and X-ray diffraction respectively. FTIR spectroscopy indicated the presence of carbonate ions, the presence of Ca element was indicated by the EDX analysis. X-ray diffraction showed the presence of calcite and $11.2 \%$ calcite was present in the film as indicated by $\mathrm{TG}$ analysis. The $30 \mu \mathrm{m}$ film consisted of a core layer of polypropylene filled with calcite and $4 \mu \mathrm{m}$ thick upper and lower layers without any filler were from different polymers. There were long air cavities in the core layer with aspect ratios of 23 and 19 in machine and transverse directions making the film pearlescent. The surfaces of the film were very smooth and had a surface roughness in the range of 3.052 and $11.261 \mathrm{~nm}$ as determined by AFM. The film melted at $436.6 \mathrm{~K}$ had $51 \%$ crystallinity and $6.3 \mathrm{~nm}$ polymer crystals for $10 \mathrm{~K} / \mathrm{min}$ heating rate. The film thermally degraded in two steps. The first step was for the polymer fraction and the second step was for decomposition of calcite. For $10 \mathrm{~K} / \mathrm{min}$ heating rate the onset of polypropylene degradation was $523 \mathrm{~K}$ and calcite decom- 
position was $943 \mathrm{~K}$. The activation energies for polypropylene degradation and calcite decomposition were 64.8 and $93.7 \mathrm{~kJ} / \mathrm{mol}$. The film reflected but not transmitted visible light. The tensile strength of the film in machine and transverse directions were different and it was 97.7 and $35.9 \mathrm{MPa}$, respectively.

\section{Acknowledgments}

The authors thanks to Bak Ambalaj Turkey for providing the pearlescent films for this study.

\section{References}

[1] Nie H., Walzak M. and McIntyre N.: J. Mat. Eng. Perform., 2009, 13, 4511.

[2] http://decrobopp.wordpress.com

[3] Longo C., Savaris M., Zeni M. et al.: Mat. Res., 2011, 14, 442.

[4] Raukula J.: PhD thesis, Technical Research Centre of Finland, 1998.

[5] Ulku S., Balkose D., Arkis E. and Sipahioglu M.: J. Polym. Eng., 2003, 23, 437.

[6] Kalapat N. and Amornsakchai T.: Surface \& Coating Techn., 2012, 207, 594.

[7] Nago S. and Mizutani Y.: J. Appl. Polym. Sci., 1998, 68, 1543.

[8] Amon M.: Pat. US 6183856B1, Publ. Febr. 06, 2001.

[9] Koleske J.: Paint and Coating Testing Manual, $14^{\text {th }}$ edn.

Gardner-Sward Ed., Philadelphia 1995.

[9] http://www.specialchem4polymers.com

[10]

http://www.plastemart.com/upload/literature/246_art_bopp_in_food pack.asp

[11] Biswas J., Kim H., Lee B. and Choe S.: J. Appl. Polym. Sci., 2008, 109, 1420 .

[12] Nie H.-Y., Walzak M. and McIntyre N.: JMEPEG, 2004, 13, 451.

[13] Nie H.-Y. , Walzak M. and McIntyre N.: Polymer, 2000, 41, 2213.

[14] Izer A., Kahyaoglu T. and Balkose D.: Zh. Volgograd Gos. Univ., 2010, 10, 16.
[15] Chen J. and Xiang L.: Powder Techn., 2009, 189, 64.

[16] Diez F., Alvarino C., Lopez J. et al.: J. Therm. Analysis Calorimetry, 2005, 81, 21.

[17] Data from JCPDS Card Index File, Card 5-5868.

[18] Yang W., Li Z-M., Xie B.-H. et al.: J. Appl. Polym. Sci., 2003, 89, 686.

[19] Bu H., Cheng S. and Wunderlich B.: Die Makromolekulare Chemie Rapid Commun., 1988, 89, 75.

[20] Yamada K., Hikosaka M., Toda A. et al.: Macromolecules, 2003, 36, 4790.

[21] http://en.wikipedia.org/wiki/Polypropylene

[22] http://www.surface-tension.de/solid-surface-energy.htm

[23]

http://www.tainstruments.co.jp/application/pdf/Thermal_Library/Ap plications_Briefs/TA125.PDF

[24] http://perlas.com.mx/en/quality/luster.html

[25] Birley A., Haworth B. and Batchelor J.: Physics of Plastics: Processing Properties and Materials Engineering. Hanser Publishers, Munich 1992.

[26] Lin Y., Dias P., Chum S. et al.: Polym. Eng. Sci., 2007, 47, 1658.

[27] Yuksekkalayci C., Yilmazer U. and Orbey N.: Polym. Eng. Sci., 1999, 39, 1216.

\section{ХАРАКТЕРИСТИКА БІАКСІАЛЬНОӤ БАГАТОШАРОВОЇ ПОЛІПРОПІЛЕНОВОЇ ПЛІВКИ 3 ПЕРЛАМУТРОВИМ ЕФЕКТОМ}

Анотація. Визначено морфологію, склад, оптичні, термальні та механічні властивості промислових перламутрових багатошарових біаксіально орієнтованого поліпропіленових (БОПП) плівок. Структура і орієнтація БОПП плівок були підтверджені IК-Фур'є-спектроскопією, рентгенівською дифракиією та енергодисперсійною рентгенівською спектроскопією. Шорсткість поверхні плівки визначали методом атомносилової мікроскопії (АCM). Межа міиності на розрив плівок була визначена в повздовжньому і поперечному напрямку.

Ключові слова: перламутрова плівка, біаксіально орієнтований поліпропілен, рентгенівська дифракиія, АCM, межа міцності на розрив. 